Jurnal Akuntansi dan Investasi, Vol. 18 No. 2, Hlm: 141-152 Juli 2017

Artikel ini tersedia di website: http://journal.umy.ac.id/index.php/ai

DOI: $10.18196 /$ jai. 180278

\title{
Mengungkap Kesadaran Islami atas Riba pada Proses Pembelajaran Akuntansi
}

Virginia Nur Rahmanti *

Prodi Akuntansi Universitas Brawijaya, Jln. Veteran, Lowokwaru, Kota Malang, Jawa Timur 65145, Indonesia

\begin{tabular}{l}
\hline A R T I C L E I N F O \\
\hline Article history: \\
received 15 Feb 2017 \\
revised 17 Apr 2017 \\
accepted 13 Jun 2017
\end{tabular}

Keywords:

Awareness; Financial

Accounting; Technology

\begin{abstract}
This research aimed to know awareness of teachers (lecturers) specifically on subject of Financial Accounting including recognition, measurement, and reporting of "interest". Muslims believe that interest is forbidden as riba. Indeed, the practice of interest is not limited as Islamic issue, but it is viewed as universal issue based on housing bubble price cycle that may affect all sectors. By employing postphenomenology as well as thought of Don Ihde, this research involving five diversified informant. The results showed that the subjects of Financial Accounting lecturer (Muslim) still stuck on "technology" (term of Ihde) in the form of international curriculum standards, reference books, and subject (course) planning.
\end{abstract}

(C) 2017 JAI. All rights reserved

\section{PENDAHULUAN}

Muslim telah meyakini bahwa riba adalah haram. Sebagian diantaranya tentu dapat mendefinisikan sekaligus menginterpretasikan istilah riba. Namun demikian, tampaknya tidak seluruh muslim dapat mewujudkan pemahamannya dalam tataran praktik. Sebelum berbincang lebih jauh, satu alasan yang mendasari penelitian ini adalah karena multiplier effect yang diakibatkan.

Banyak peneliti sebelumnya yang pernah meneliti tentang riba. Sebut saja Khan (2008) yang membahas tentang praktik perbankan syariah; Aliyev (2007) tentang transaksi mudharabah; Ardiansyah (2009) tentang kinerja bank syariah; serta Hayat dan Kraeussl (2010) terkait penilaian risiko pada perbankan syariah. Dari penelitian ini tampak bahwa pembahasan masih terbatas pada definisi riba yang dikaitkan dengan praktik dalam perbankan syariah. Hanya beberapa diantaranya yang mengulas lebih dalam tentang konsep riba, seperti Kamla (2009), dan Haniffa dan Hudaib (2010) dalam penelitiannya yang berjudul "Sacred and Secular Goals". Berbeda dengan penelitianpenelitian tersebut, penelitian ini ingin mengamati sejauh mana kesadaran muslim (diwakili oleh dosen) atas praktik riba dalam kehidupan seharihari. Kekhawatiran yang muncul atas ketidaksadaran atau justru "sengaja tidak menyadarkan diri“ untuk mengenalkan, mengajarkan, bahkan mempraktikkan riba. Melalui penelitian ini, diharapkan akan dapat menemukan benang merah tentang apakah Islam kini hanya dimaknai sebagai teori yang mengarah pada sekulerisasi, atau memang Islam telah meliputi seluruh sendi kehidupan yang bersifat "sakral" (meminjam istilah Haniffa dan Hudaib 2010) dengan mengeksplorasi kesadaran muslim tentang riba. Proses penggalian ini dilakukan dengan meneliti apakah larangan riba hanya dimengerti secara teori definitif seperti yang dijelaskan dalam mata kuliah Agama, ataukah subjek peneliti memang benarbenar sadar akan hal ini yang terefleksi dari kehidupan mereka melalui aktivitasnya sebagai dosen.

Ilmu sosial, ada pula yang menyebut "humaniora", lebih spesifik ilmu akuntansi diyakini sebagai tools yang bebas nilai (Mulawarman, 2013). Hal serupa disitir pula oleh Nofianti (2012) dari Sudibyo (1987) yang menyimpulkan bahwa akuntansi memang diyakini sebagai teknologi. Sebagai konsekuensinya, akuntansi dinilai sebagai suatu ilmu yang berhubungan dengan hal teknis yang tidak dapat memengaruhi suatu peradaban. Akuntansi dianggap hanya sebagai alat, benda mati, yang tidak memiliki kekuatan. Ini tercermin dari siklus akuntansi yang hanya sarat dengan angka, akun, jurnal dan berakhir di laporan keuangan. Berbeda dengan pandangan ini, peneliti lain seperti Triyuwono (2000), menilai sebaliknya, bahwa akuntansi tidak bebas nilai. Akuntansi bukan lagi dianggap sekedar alat, namun ilmu ini dapat mengubah suatu peradaban. Akuntansi akan menjadi baik jika si pengguna 
memanfaatkannya untuk tujuan yang baik dan sebaliknya. Jadi akuntansi tidak semata-mata dipandang sebagai kumpulan angka, namun dalam akuntansi itulah terselip suatu nilai yang melekat di dalamnya. Inilah yang kemudian memunculkan kekhawatiran bahwa sebagian akuntan' akan menjadi si pengguna yang "keblinger". Para pengguna yang "keblinger" ini merujuk pada sebagian dintara anggota suatu profesi yang memegang peranan penting dalam membangun kesadaran para calon akuntan (mahasiswa) tentang riba, yaitu Dosen. Dalam konteks pembahasan ini peran dosen dapat dianalogikan sebagai zat pewarna yang akan memengaruhi pola pikir mahasiswa menjadi putih, hitam, biru, dan sebagainya. Para mahasiswa inilah yang nantinya akan menjadi pelaku dalam menentukan warna suatu peradaban. Inilah titik krusial peran dosen.

Mayoritas dosen yang pernah atau sedang mengajari Anda (mahasiswa) tentang ilmu akuntansi adalah muslim. Ilmu akuntansi yang secara umum ditawarkan oleh universitas diantaranya meliputi akuntansi keuangan, auditing, perpajakan, sistem, manajemen keuangan, akuntansi biaya, etika, dan teori akuntansi. Namun penelitian ini secara khusus mengajak Anda untuk mengerucutkan diskusi kita pada dosen pengajar subjek tertentu, yaitu akuntansi keuangan. Mengapa akuntansi keuangan? Jawabnya sederhana, karena dalam mata kuliah inilah mahasiswa diajarkan tentang pencatatan, pengakuan, dan pelaporan bunga. Sebagai pengajar akuntansi keuangan, adalah hal yang wajar untuk menyampaikan konsep perhitungan bunga kepada para mahasiswa. Menjadi wajar karena textbook yang dipilih memang orisinal dari Barat yang diyakini "kebenarannya". Bukan hanya itu, penyampaian bunga ini menjadi semakin wajar ketika kita dihadapkan dengan konsensus global (melalui standar internasional) yang mau tidak mau harus diikuti, karena konon katanya Indonesia merupakan bagian dari organisasi internasional, dan salah satunya yaitu yang sedang hangat diperbincangkan, menjadi anggota Masyarakat Ekonomi ASEAN (MEA). Anggapan akan kewajaran inilah yang tampaknya membuat para dosen ini menjadi "keblinger", sehingga menganggap penyampaian bunga menjadi proses biasa yang dikuatkan dengan standarisasi silabus.

Sementara itu, Al Qur'anul Karim dan hadist telah menyampaikan secara tegas akan larangan

\footnotetext{
${ }^{1}$ Mereka yang pro pada pandangan bahwa akuntansi tidak bebas nilai
}

riba. Kontradiksi inilah yang mengusik peneliti. Apakah mungkin fenomena ini terjadi sebagai salah satu akibat dari sekulerisasi pendidikan khususnya bidang akuntansi ${ }^{2}$, sehingga Tuhan hanya dihadirkan dalam mata kuliah Agama. Kita hanya ingat dosa jika berbicara tentang agama dimana saat itulah Tuhan dihadirkan, kemudian selebihnya kembali ke model kehidupan sekuler yang lebih memilih mengikuti peraturan temporer buatan manusia daripada Tuhan yang terejawantahkan melalui Al Quranul Karim.

Mendasarkan pada kondisi di atas, penelitian ini ingin mengetahui sejauh mana kesadaran muslim tentang riba dalam konteks pembelajaran akuntansi. Muslim di Indonesia khususnya, merupakan bagian dari sistem sosial yang meliputi masyarakat non-Islam. Seperti yang kita ketahui bersama, Negara sekuler tidak pernah mempermasalahkan akan praktik riba. Sementara dalam globalisasi peradaban saat ini mereka tampak sebagai Raja yang dapat membuat suatu peraturan untuk diikuti para pengikutnya yang lebih tidak berdaya. Sebut saja sebagai pihak Negara maju dan berkembang. Posisi Indonesia sebagai Negara berkembang inilah yang tampaknya mengakibatkan masyarakat muslim masih cenderung terkontaminasi oleh sekulerisasi. Ketidakberdayaan ini tercermin pula dari jenis keanggoataan dunia yang diikuti oleh Indonesia yang mengharuskannya untuk mentaati seluruh aturan/pedoman yang diterapkan oleh perkumpulan Negara maju.

Penelitian ini dibagi menjadi dua pembahasan, bagian pertama akan mendeskripsikan tentang hasil refleksi mahasiswa atas model pembelajaran akuntansi oleh dosen pengajarnya. Kemudian dilanjutkan dengan bagian kedua, yaitu mengulas tentang pemahaman riba oleh beberapa perwakilan dosen pengajar mata kuliah akuntansi keuangan. Dari dua tahapan ini, diharapkan dapat ditarik benang merah apakah konsep Islam yang dalam penelitian ini diwakili oleh riba, telah meliputi/menginternalisasi dalam kehidupan para muslim yang diwakili oleh beberapa dosen. Dosen dipilih sebagai salah satu subjek penelitian karena mengingat perannya yang sangat penting dalam

\footnotetext{
2 Learning outcome pada sebagian besar mata kuliah akuntansi keuangan di luar negeri bahkan di Indonesia. Dalam KKNI, terdapat satu pernyataan percaya dan taat pada Agama. Namun setelah diturunkan pada proses penyusunan LO per mata kuliah, pernyataan ini hanya diakomodasi pada mata kuliah AGAMA. Lalu bagaimana dengan yang lainnya? Tuhan tidak ada!, karena Tuhan hanya ada pada mata kuliah Agama.
} 
menentukan warna suatu peradaban muslim ke depan melalui anak didiknya (mahasiswa).

Dari penelitian ini diharapkan dapat memberi kontribusi teoritis untuk menjadi acuan dalam penyusunan kurikulum dengan memasukkan nilai-nilai religius. Sementara untuk kontribusi praktis, diharapkan dapat menjadi bahan kontemplasi bagi kita para pendidik dalam mendiseminasikan keilmuan bidang akuntansi terutama yang mengandung konsep bunga.

\section{TINJAUAN LITERATUR DAN FOKUS PENELITIAN}

Menurut bahasa "riba" berarti "ziyadah" (tambahan). Sedang menurut pengertian Syara', adalah: tambahan atau kelebihan tanpa imbalan jasa atau barang yang diharuskan bagi salah satu dari dua orang yang mengadakan akad. Kemudian, adakah riba itu diharamkan? Jawabannya adalah: Iya. Beberapa dalil yang menunjukkan hukum riba itu haram ialah ayat Al-Qur'an dan Sunnah Rasul. Larangan riba muncul dalam AlQur'an dan $4 \mathrm{x}$ penurunan wahyu yang berbedabeda, yaitu: a) Ar-Ruum: 39, diturunkan di Mekah, menegaskan bahwa bunga akan menjauhkan keberkahan Allah dalam kekayaan, sedangkan sedekah akan meningkatkannya terlipat ganda, b) An-Nisaa': 161, diturunkan pada masa permulaan periode Madinah, mengutuk dengan keras praktek riba, seirama dengan larangannya pada kitab-kitab terdahulu.

Pada tahap kedua ini, Al-Qur'an mensejajarkan orang yang mengambil riba dengan mereka yang mengambil kekayaan orang lain secara tidak benar dan mengancam kedua pihak dengan siksa Allah yang amat pedih. Melanjutkan kutipan ayat Al Quran, c) Ali 'Imron: 130-132, diturunkan pada kira-kira tahun kedua atau ketiga Hijrah, menyerukan kaum muslimin untuk menjauhi riba jika mereka menghendaki kesejahteraan yang diinginkan (dalam pengertian Islam yang sebenarnya), dan d) Al-Baqarah: 275-281, diturunkan menjelang selesainya misi Rasulullah SAW mengutuk keras mereka yang mengambil riba, menegaskan perbedaan yang jelas antara perniagaan dan riba, dan menuntut kaum muslimin agar menghapuskan seluruh utang-piutang yang mengandung riba, menyerukan mereka agar mengambil pokoknya saja, dan mengikhlaskan kepada peminjaman yang mengalami kesulitan. Rasulullah juga mengutuk, dengan mengsunakan kata-kata yang sangat terang, bukan saja mereka yang mengambil riba, tetapi juga mereka yang memberikan riba dan para penulis yang memberikan riba dan para penulis yang mencatat transaksi atau para saksinya. Bahkan beliau menyamakan dosa orang yang mengambil riba dengan dosa orang yang melakukan zina 36 kali atau setara dengan orang yang mengzinai ibunya sendiri. "Padahal Allah telah menghalalkan jual beli dan mengharamkan riba". Dari ayat tersebut jelas dapat difahami bahwa hukum riba adalah haram”.

Hadists yang diriwayatkan oleh BukhariMuslim yang artinya : ”auilah tujuh hal yang merusak ; maka ada yang menanyakan hal itu: ya Rasulullah apa yang dimaksud dengan perusak itu? Nabi menjawab: Memusyrikkan Allah, melakukan sihir, membunuh yang diharamkan Allah, makan riba, makan harta anak yatim, lari dari pertempuran dihari penyerbuan dan menuduh zina wanita mukmin yang baik. Dari ayat dan Hadist diatas, diketahui bahwa riba itu hukumnya haram

Bahaya riba tentu tidak hanya berdampak pada pribadi seserang, melainkan juga memengaruhi masyarakat. Tentu terdapat suatu alasan sehingga riba diharamkan dalam Islam. Mengutip Siddiqi (2004:41) yang membaginya menjadi lima alasan, yaitu:

(1) Riba merugikan masyarakat

(2) Riba berarti perampasan atas harta milik orang lain

(3) Riba menyebabkan perkembangan masyarakat yang negatif

(4) Riba merendahkan martabat seseorang

(5) Riba berarti tidak adil

Mengacu pada sumber yang sama, alasan pertama didukung oleh Al-Qur'an surat Ar Rum (30) ayat ke-39 dan 41 bahwa;

“.....Dan sesuatu riba (tambahan)yang kamu berikan agar harta manusia bertambah, maka tidakk bertambah dalam pandangan Allah. Dan apa yang kamu maksudkan untuk memperoleh keridhaan Allah, maka itulah orang-orang yang melipatgandakan (pahalanya)”. [QS. Ar Rum (30): 39]

“...Telah tampak kerusakan di darat dan di laut disebabkan karena perbuatan tangan manusia; Allah menghendaki agar mereka merasakan sebagian dari (akibat) perbuatan 
mereka, agar mereka kembali (ke halan yang benar)". [QS. Ar Rum (30): 41]

Dari dua ayat ini tampak bahwa membebankan suatu tambahan (riba) merupakan perbuatan keliru yang merugikan masyarakat.

Selanjutnya, alasan kedua tentang perampasan hak milik orang lain, Siddiqi (2004) mengutip Khan dan Mirakor (1987) mengungkapkan bahwa ketika terjadi transaksi hutang piutang antara si peminjam dan pemilik dana, maka pada saat itulah hak milik si peminjam atas suatu harta akan menjadi milik si pemilik dana tanpa ada suatu legitimasi yang jelas.

Sementara atas alasan ketiga, Siddiqi kembali menyampaikan bahwa aktivitas riba memang secara nominal akan menambah jumlah kepemilikan harta bagi si pemilik dana, namun secara makro gagal memberikan pertumbuhan positif kepada masyarakat. Bagi pelaku yang melakukan transaksi ribawi, sebetulnya akan merendahkan martabatnya. Mengapa demikian?. Mari kita menelaah kutipan surat $\mathrm{Al}$ Baqarah 275 berikut:

“......... padahal, Allah telah menghalalkan jual beli dan mengharamkan riba. Barang siapa mendapat peringatan dari Tuhannya, lalu dia berhenti, maka apa yang telah diperolehnya dahuly menjadi miliknya dan urusannya (terserah) kepada Allah. Barang siapa mengulangi, maka mereka itu penghuni neraka, mereka kekal di dalamnya.” [QS. Al Baqarah (2): 275]

Jelas Allah membedakan dua istilah antara jual beli dan riba. Namun karena mereka (para pelaku transaksi ribawi) menyamakan antara aktivitias jual beli dan riba, maka inilah yang akan merendahkan martabatnya.

Alasan yang terakhir yaitu tentang ketidakadilan, tentu transaksi ribawi memuat ketidakadilan antara si peminjam dan pemilik atas dana yang dipinjamkan. Tidak adil atas tambahan dana yang telah dipersyaratkan di awal tansaksi yang tentunya akan merugikan pihak peminjam.

\section{METODE PENELITIAN}

Dalam upaya untuk menganalisis kesadaran dalam proses pembelajaran akuntansi, penelitian ini menggunakan metode postfenomenologi dari pemikiran Don Ihde. Ihde yang mulai merambah bidang persepsi tahun 1970, akhirnya melahirkan buku bernuansa teknosains pada tahun 1976-
1977, lebih rinci mengulas tentang fenomenologi pengalaman audio dan visual. Lebih lanjut, mengutip tesis Ihde yang berbunyi "manusia 'menubuh' dengan alat-alat teknologi, yaitu instrument". Istilah "menubuh" memiliki arti bahwa alat dijadikan sebagian dari cara persepsi tubuh manusia, dan melalui alat ini manusia melakukan aktivitasnya dalam dunia (kehidupan). Metode ini merupakan Ihde berpandangan bahwa manusia itu layaknya mesin yang beraktifitas tanpa sadar. Mengutip Selinger (2006:4), menurut Ihde, terdapat hubungan antara manusia-teknologi (human-technology). Keterlibatan manusia sepenuhnya pada suatu teknologi dapat mengakibatkan perubahan eksistensial yang sangat dramatis, khususnya pada proses pemahaman dunia dan humanity.

Pemikiran inilah yang peneliti gunakan untuk menganalisis informasi yang diperoleh dari para informan. Apakah selama proses pengajaran khususnya subjek akuntansi keuangan telah secara sadar akan larangan praktik bunga? Dan apakah mereka sesungguhnya sadar bahwa bunga adalah riba?. Parameter atas kesadaran ini tercermin dalam proses penyampaian materi (pembelajaran), apakah mereka mengaitkan antara ilmu akuntansi konvensional dengan isu bunga ini. Bunga yang diyakini oleh muslim sebagai riba bukanlah terbatas pada isu Islami, namun mengamati multiplier effect yang disebabkan oleh siklus housing bubble price, praktik bunga seharusnya diyakini sebagai isu universal ${ }^{3}$.

Penelitian ini melibatkan sejumlah 5 (lima) informan yang terdiri dari 2 mahasiswa S-1 (semester 3 dan 7) pada Universitas A, 1 mahasiswa pascasarjana pada Universitas A, 1 mahasiswa pada Universitas B, dan 1 dosen pengajar akuntansi keuangan kelas Internasional pada Universitas. Setelah peneliti melibatkan kehadiran informan, tahapan berikutnya adalah melakukan analisis dengan menggunakan pemikiran Don Ihde. Seperti yang telah disampaikan pada tahapan metode, bahwa tesis dari pemikiran Ihde adalah manusia yang menubuh dengan instrumen. "Manusia" dalam penelitian ini diwakili oleh para pengajar yang berlatar belakang muslim, dan "instrument" diwakili oleh buku ajar produksi oksidental. Jika pengajar muslim yang notabene mengetahui bahwa hukum bunga adalah haram, maka melalui pemikiran Ihde peneliti

\footnotetext{
${ }^{3}$ Istilah housing bubble price dikutip dari Holt 2009

Salah satu prinsip Islam adalah universalisme (syumuliyah) yang berarti tidak terbatas pada muslim, namun meliputi masyarakat non-muslim.
} 
ingin mengetahui apakah pengetahuan tersebut telah menginternalisasi dalam diri mereka dalam proses menyebarkan ilmu akuntansi yang sarat dengan bunga. Konsep bunga dalam buku referensi akuntansi yang dipakai oleh para pengajar akuntansi di institusi yang menjadi situs penelitian tentu tidak dapat dihindari, sebab buku acuan yang digunakan merupakan produksi Barat.

\section{HASIL DAN PEMBAHASAN}

\section{Mengapa Meneliti Riba?}

Bagi muslim, riba merupakan istilah yang seharusnya dikenal dengan baik. Definisi riba dan implementasi atas konsep riba ini peneliti rasa semua muslim memahami. Namun ketika peneliti coba bertanya kepada mayoritas muslim tentang riba, jawabnya selalu mengerucut pada satu kesimpulan: riba berarti bunga. Pada bagian awal penelitian ini, peneliti ingin menelaah dampak penerapan riba dilihat dari sudut pandang ekonomi makro. Kita tentu masih ingat dengan peristiwa subprime mortgage yang saat itu (2008) gencar sekali diperbincangkan. Kegoncangan ekonomi ini terjadi karena keterlibatan peran riba. Disebut housing bubble price, suatu siklus yang berawal dari investasi besar-besaran pada sektor finansial. Mengapa sektor ini yang menjadi incaran para feodal?, karena melalui sektor inilah mereka memperoleh pengembalian lebih cepat dan tentunya hampir bebas risiko. Berbeda dengan sektor riil yang cenderung berisiko tinggi dengan tingkat pengembalian investasi yang tidak menjanjikan.

Mengulas tentang risiko, Wahyudi et al. (2013) menegaskan bahwa Islam tidak boleh mengakui segala pendapatan dan keuntungan yang diperoleh tanpa diikuti oleh risiko. Jika ini yang terjadi, maka inilah yang disebut riba. Kembali melanjutkan siklus housing bubble price, jika para pemilik modal serentak berinvestasi pada sektor finansial, maka jumlah permintaan pasti akan merangkak naik. Sesuai hukum ekonomi, jika permintaan naik maka harga pasti mengikuti. Peristiwa ini terus berlangsung hingga pada suatu saat gelembung ini akan meledak. Padahal sektor finansial merupakan jantung perekonomian suatu negara. Jadi dapat dibayangkan betapa besar dampak yang disebabkan oleh housing bubble price ini. Bukan saja sektor keuangan yang terpengaruh, sektor rïl sebagai bagian kecil dari "permainan" ini ikut terkena imbasnya.

Penelitian ini mencakup bidang akuntansi syariah (islamic accounting) lebih spesifik tentang kesadaran Islami atas riba. Chong dan Liu (2007) secara tegas mengungkapkan bahwa "In Islam, there is no separation between mosque and state, Business, similarly, cannot be separated from the Islamic religion". Istilah ini memilliki makna senada dengan ungkapan peneliti sebelumnya bahwa agama dan aktivitas ekonomi tidak dapat dipisahkan. Jika ini terjadi, maka sekulerisasi yang akan terjadi. Peneliti yakin diantara kita terkadang beranggapan pemikiran ini terlalu berlebihan karena kita dianggap sok suci, sok agamis, dan tidak mendunia. Apalagi memasukkan nilai-nilai agama dalam subjek mata kuliah akuntansi keuangan contohnya, dalam benak kita mungkin terbesit apa jadinya akuntansi keuangan kok dimasuki prinsip keadilan, kemaslahatan, keseimbangan dan seterusnya. Atau, kalau seluruh subjek memuat nilai Agama bisa jadi seluruh universitas menjadi Universitas yang berbasis Islam. Bukankah ini yang justru lebih baik daripada berbasis sekuler?.

Melanjutkan penelitian Chong dan Liu (2007), menurutnya satu alasan mengapa Islam melarang riba, dengan membawa kita kembali ke jaman pertengahan abad lalu ketika orang Arab sedang gencar mengenakan pengembalian berlipat (doubling the debt) jika si peminjam gagal melunasi hutangnya yang telah jatuh tempo. Lebih buruk lagi, transaksi ribawi ini diterapkan kepada para budak yang tidak memiliki suatu legislasi yang menjamin atas hutangnya. Memang pada saat itu terjadi gap sangat lebar antara kelompok kaya dan miskin yang diwakili oleh para budak. Pemandangan yang tampak tidak lain berupa penindasan pada kaum yang tidak bermodal dengan mekanisme hutang piutang yang berbunga. Atas praktik inilah kemudian Chong dan Liu (2007) menyimpulkan larangan riba ini sebagai salah satu visi besar Islam atas moral dalam ekonomi.

Melanjutkan tentang pandangan Islam tentang riba, Haniffa dan Hudaib (2010) mengingatkan kembali tentang sejarah Islam dimana era 1960 merupakan masa pembangunan ekonomi muslim dunia yang mengarah pada ketaatan syariah, salah satunya penghindaran atas riba. Melalui penelitiannya ini, mereka menukil ayat $\mathrm{Al}$ Quranul Karim berikut ini: 
"Hai orang-orang beriman, bertakwalah pada Allah dan tinggalkan sisa riba jika kamu orangorang yang beriman. Maka jika kamu tidak melaksanakan (apa yang diperintahkan ini) maka ketahuilah, bahwa akan terjadi perang dahsyat dari Allah dan RosulNya dan jika kamu bertaubat maka bagi kamu pokok harta kamu, kamu tidak dianiaya dan tidak (pula) dianiaya”. [QS. Al-Baqarah (2): 278-279]

Bahkan melalui cuplikan ayat ini, Allah SWT secara terang mengumumkan "perang" beserta Rasul-Nya atas orang yang mempraktikkan riba. Dengan berhenti (taubat) dan atau menghindari riba sesungguhnya kita bukan tergolong sebagai manusia pembawa kerugian bagi masyarakat dan tentunya akan terhindar dari "kerugian" .

Penelilitian Haniffa dan Hudaib (2010) juga menjelaskan bagaimana praktik/transaksi ekonomi yang bertentangan dengan Islam justru marak terjadi pada kaum muslim. Lebih spesifik, mereka menurunkan praktik ekonomi ini pada sistem keuangan Islam modern berserta institusinya yang banyak terpengaruh oleh keberadaan non-muslim. Inilah yang menyebabkan pencapaian tujuan pemenuhan ketaatan syariah (sharia compliance) salah satunya melalui penghindaran riba, menjadi salah arah.

Bentuk nyata dari dominasi pengaruh Barat sudah mulai tampak sejak tahun 90' an pada bidang politik dan keuangan syariah, yang diistilahkan oleh Henry dan Springborg (2001) sebagai the "New World Order". Istilah ini mengarah pada pembentukan dan standarisasi suatu aturan yang berlaku global. Nah, salah satu produknya bisa jadi IFRS yang menuntuk para akuntan untuk dapat menyusun laporan keuangan dengan standart tertentu sehingga produknya dapat diterima dunia. Meskipun secara substansi bertentangan dengan prinsip Islam seperti diuraikan sebelumnya, tampaknya bukan lagi menjadi masalah. Mengapa? Sederhana saja jawabnya, karena Muslim telah "keblinger" dengan sentimen globalisasi. Penelitingnya tanpa kita sebagai bagian dari negara berkembang kurang peka atas dampak dari globalisasi tersebut. Kembali Haniffa dan Hudaib (2010) mengungkapkan "Washington Consensus" sebagai suatu kebijakan yang mendiskreditkan negara berkembang.

\footnotetext{
${ }^{4}$ Peneliti mengasumsikan kerugian dalam konteks ini adalah "perang" yang diserukan oleh Allah dan Rasul-Nya dengan cara-Nya yang tidak kita sangka

${ }^{5}$ It is a term describing a set of ten specific economic policy prescriptions in the standard
}

\section{Bagian I: Menemukan Teknologi "Ihde" dalam Proses Pengajaran Akuntansi}

Seperti yang telah peneliti ungkapkan sebelumnya, penelitian ini ingin menelaah sejauh mana dosen pengampu mata kuliah yang mencakup perhitungan bunga, mentransfer materi kepada para mahasiswa. Apakah pada saat menyampaikan materi tersebut kita sadar bahwa Islam melarang konsep riba?, atau apakah kita sadar bahwa bunga dilarang adalah ketika menghadiri pengajian?. Inilah yang akan peneliti teliti di awal bagian kedua. Berikutnya disambung dengan uraian jawaban atas permasalahan yang sama dengan menyertakan praktisi institusi keuangan syariah sebagai informan.

Peneliti memperoleh data awal dari hasil interviu dengan beberapa mahasiswa yang memenuhi kriteria pernah menjadi mahasiswa pada mata kuliah $\mathrm{X}$ yang di dalamnya membahas tentang perhitungan bunga. Pertanyaan yang peneliti utarakan bukan tentang pendapat mereka akan mata kuliah ini, namun observasi atas "cara" sang dosen (muslim) mentransfer materi termasuk perhitungan bunga. Untuk memperoleh hasil yang valid, peneliti pun mengajak 5 (lima) responden mahasiswa muslim yang pernah diampu oleh dosen yang berbeda. Sebut saja mereka "A", "B", "C", "D", dan "E". Melalui observasi selama mereka menempuh satu mata kuliah (satu semester), peneliti rasa sangat mumpuni bagi mereka untuk menarik suatu kesimpulan tentang hal yang ingin peneliti cari.

Sebelum menguraikan informasi yang peneliti peroleh dari kedelapan informan, peneliti hendak membuka perbincangan kita dengan mengutip penelitian Choudhury (2008), bahwa epistemologi berpikir Islam dan liberal berkebalikan dalam hal konsep, formal, dan praktik. Oleh karena itu, imbuhnya, pemahaman atas ekonomi, masyarakat, globaliasi dan sistem-dunia yang melekat di dalamnya, pasti saling bertentangan.

Pada bagian ini, seperti yang telah disampaikan sebelumnya, peneliti hendak menyampaikan hasil perbincangan dengan para informan. Pertama, seorang mahasiswa yang telah menyelesaikan semester 3, yang telah menempuh dua mata kuliah core Akuntansi, yaitu A, memulai ceritanya sebagai berikut:

\footnotetext{
reform package by US-based institutions such as the IMF and World Bank to crisis-wracked developing countries (Williamson 1989)
} 
"Waktu saya menempuh mata kuliah core Akuntansi, Dosen bernama " $\mathrm{X}$ " memang pernah sedikit mengulas tentang riba”. Beliau berpandangan bahwa Dosen hanya menyampaikan ilmu bagi mahasiswa, selebihnya terserah bagaimana menggunakannya, kewajiban Dosen hanya menyampaikan”.

Sementara itu Dosen kedua, "Y", pada mata muliah core akuntansi lainnya yang ditempuh "A" tidak pernah menyampaikan tentang riba dalam pembahasan mata kuliahnya . Dalam penilaian singkatnya, "A" mengungkapkan, "larangan atas praktik riba ini memang tampak lebih terinternalisasi pada dosen yang pertama, sementara dosen kedua menyampaikan materi yang bersifat sangat teknis.

Melanjutkan tentang metode pengajaran, dosen pertama dalam satu pertemuan kuliah sengaja menyampaikan tentang bunga. Definisi, jenis, dampak, beserta ulasan kasus tentang praktik bunga. Meskipun bertentangan dengan keyakinannya untuk menghindari bunga, beliau menegaskan karena kewajibannya sebagai Dosen maka menjadi suatu keharusan untuk menyampaikannya. Selebihnya pada level implementasi, beliau memberikan kebebasan pada mahasiswa untuk memilih, setelah sebelumnya diberikan satu ulasan pembahasan tentang bahaya riba. Inilah yang masih sangat jelas diingat oleh "A". Sementara itu, dosen kedua yang menurutnya banyak menyampaikan materi teknis tidak meninggalkan jejak pemahaman riba dalam keterkaitannya dengan salah satu mata kuliah core akuntansi tersebut. Tampaknya pula, dosen kedua ini memang memiliki focus pada penyampaikan materi sesuai tujuan yang dingin dicapai dalam silabus.

Inilah yang disebut oleh Lehman (2011) dengan "We are what we eat; and teach". Satu ungkapan yang sangat cocok dengan penelitian ini. Mengutip Williams (2004), Lehman menyebutkan "They are the result of the . . questionable values that shaped their parallel developments". Kepribadian seseorang merupakan hasil dari nilai-nilai yang membentuknya melalui perjalanan yang dilaluinya. Ketika selama perjalanan pengembaraan seseorang mendapatkan bekal ilmu yang baik, maka mendasarkan pada kutipan tersebut, seseorang itu pasti akan baik dan sebaliknya (we are what we eat). Sementara itu, disadari atau tidak, kita sebagai bagian dari pengajar ternyata secara perlahan dapat merubah pemikiran murid hingga merubah perilakunya. Jika sang guru membekali dengan nilai-nilai keburukan, maka hampir dapat dipastikan si murid akan terbentuk sama seperti apa yang diajarkan sang Guru, dan sebaliknya. Dan ini pulalah yang menunjukkan pula seperti apakah kita sebagai seorang pengajar (we are what we teach). Bukan hanya itu, peneliti lain Buck-Morss (2009:ix) mengungkapkan "what we think we know about the past, and therefore how we think in the present".

Dengan demikian, anak didik kita yang saat ini telah berkarya dalam berbagai profesi dengan segala "tingkah" baik dan buruknya, sebenarnya merupakan produk atas proses masa lalunya. Kirakira, apa yang peneliti maksud dengan proses masa lalu?. Tepat!, proses penerimaan ilmu selama mereka sekolah. Mari kita ambil contoh sederhana, ketika mereka diajarkan dengan ilmu sekuler sudah hampir bisa dipastikan nantinya ilmu itu pasti akan memengaruhi cara berpikirnya. Ini karena mereka diajarkan untuk tidak terbiasa selalu berdampingan dengan Tuhan. Tuhan hanya ada di tempat peribadatan, Tuhan hanya ada di mata pelajaran tertentu, dan seterusnya. Oleh karena itu, mungkin saja peristiwa fraud yang sedang marak terjadi di negara kita sejak satu dekade belakangan ini yang ditandai dengan kemunculan para koruptor, merupakan produk atas contoh sederhana itu.

Jika Anda masih penasaran dimana keterkaitan penelitian ini dengan ilmu akuntansi mari peneliti tunjukkan contoh berikutnya yang peneliti kutip dari Buck-Morss (2009), bahwa:

Di luar diskursus akuntansi dan bisnis, BuckMorss (2009) menantang" apa yang kita pikir kita ketahui tentang masa lalu, dan karena itu bagaimana kita berpikir di masa sekarang "(Buck-Morss, 2009, hal. ... Sarjana akuntansi kritis mengetahui dengan baik hubungan antara ekonomi dan hubungan sosial yang tak terelakkan, dan juga bertanya-tanya bagaimana istilah seperti memaksimalkan utilitas dan rasionalitas dimasukkan untuk membenarkan setiap jenis kebijakan ekonomi dan sosial dengan mengabaikan dampak yang menghancurkan terhadap yang paling rentan".

Dengan demikian, apa yang kita peroleh dari proses masa lalu maka itulah yang akan kita terapkan saat ini. Sementara itu, menurutnya akuntansi saat ini masih berputar pada maksimalisasi utilitas dan rasionalitas dimana sifat ini dimiliki oleh sang negara Barat yang memiliki kekuatan sangat besar untuk mempengaruhi negara lain. 
Melanjutkan diskusi dengan mahasiswa akuntansi, berikutnya peneliti pun mengundang informan kedua, "B" yang saat ini tengah menyelesaikan skripsinya. Dengan mengarahkan topik pembicaraan yang sama, menurutnya mata kuliah akuntansi yang disampaikan hanya terkait dengan permahaman dan perhitungan teknis. Berikut kutipan atas penjelasan si Baba:

"Yang saya pelajari kan akuntansi konvensional, yang disampaikan pasti pernah berkaitan dengan bunga. Tapi setau saya beliau cuma ngajar biasa nggak ada informasi dan masukan-masukan tentang sisi negatif bunga dan hal lain yang terkait, sehingga materi yang disampaikan terpukau sama buku”.

Berbeda dengan " $A$ ", dosen pengajar "B" ini tampaknya menyampaikan materi akuntansi yang mencakup konsep dan teknis pencatatan mengikuti alur buku saduran dari luar negeri. Sebagai informasi, seluruh informan menggunakan satu sumber buku yang sama, yaitu saduran dari luar negeri yang konon katanya negeri itu cenderung kapitalis bahkan sekuler. Rahman (2003) mengutip Al-Attas (1995), secara tegas menyinggung hal ini:

\footnotetext{
"Berbeda dengan filsafat sekuler Barat sebagaimana dicontohkan oleh Kantian. Etika, di mana penekanannya lebih pada pencerahan rasionalitas dan keyakinan kuat akan kekuatan akal, pandangan dunia Islam tidak sematamata berasal dari unsur budaya dan filosofis yang dibantu oleh ilmu pengetahuan, namun sumber yang asli adalah Wahyu, dikonfirmasi oleh agama, dan Ditegaskan oleh prinsip intelektual dan intuitif".
}

Kutipan ini jelas sekali menunjukkan perbedaan fundamental antara pandangan Barat (western) dan Islam. Barat memang masih diyakini cenderung menggunakan kekuatan rasional, sementara Islam mendasarkannya pada wahyu (Revelation) yang dikonfirmasi oleh agama, dan akhirnya diafirmasi oleh intelekstualitas. Oleh karena itu, tidak heran jika referensi Barat tidak menyinggung wahyu dan agama, namun hanya mengedepankan rasionalitas. Jadi, apakah layak bagi kita khususnya muslim yang diajarkan tentang wahyu dan agama justru memilih mengikuti paradigma yang berseberangan?. Padahal Allah menciptakan manusia dengan satu tujuan, patuh kepada-Nya seperti mengutip QS 51:56, yang berbunyi "Dan Aku tidak menciptakan jin dan manusia melainkan supaya mereka menyembah-
Kü. Al-Faruqi (1982) menggunakan istilah "obedient" untuk menunjukkan kewajiban atas eksistensi manusia.

Tidak berhenti pada buku acuan, para pengajar akuntansi pun berkewajiban pula untuk menghubungkan setiap bab dengan Pernyataan Standar Akuntansi Keuangan (PSAK) dan aturan akuntansi lainnya yang terkait. Sekali lagi, PSAK ini pun hasil adaptasi dari "luar" layaknya buku acuan. Dengan demikian, simpulan sementara Baba tentang "terpukau sama buku" tampaknya memang benar. Ini diperkuat oleh SAP seluruh universitas tempat para informan memperoleh ilmu akuntansi, yang mewajibkan mahasiswanya menggunakan satu jenis acuan yang sama. Nah, inilah yang oleh Ihde disebut sebagai "teknologi". Bukti bahwa para pengajar mungkin tidak sadar telah embeded dengan tekonologi yang disampaikan berulang kepada mahasiswa. Lebih kuat lagi, teknologi ini disepakati oleh dunia untuk disampaikan dan diterapkan.

Tentang koridor tertentu yang harus diikuti dalam penyusunan SAP ini, informan ketiga bernama "C" yang barusaja menyelesaikan kuliah di universitas yang berbeda dari "A" dan "B", juga ikut berpendapat:

\begin{abstract}
"Kalau saat ini, mulai masif tahun 2008, sudah mulai bermunculan dosen akuntansi yang menyampaikan bahwa bunga dilarang, namun dulu ketika saya masih kuliah masih sangat jarang yang menyampaikan. Kalau diijinkan oleh universitas, ya bisa dipraktikkan. Beliau tidak menyampaikan kalo riba dilarang mungkin karena tidak paham, atau sudah terbiasa dengan konven”.
\end{abstract}

Tentunya penyusunan SAP ini pasti berlandaskan pada satu aturan tertentu. Adalah International Education Standard (IES), yang diadaptasi oleh Indonesia dimana "sikap" yang pertama berbunyi "Bertaqwa kepada Tuhan Yang Maha Esa dan mampu menunjukkan sikap religius”. Nah, uniknya sikap ini hanya terejawantah dalam mata kuliah Agama, sementara mata kuliah lainnya tidak memuat Tuhan. Berikut peneliti mengambil kutipan dari IES (2014) yang relevan dengan pembahasan ini:

This International Education Standard (IES) prescribes the learning outcomes for technical competence that aspiring professional accountants are required to demonstrate by the end of Initial Professional Development (IPD). Technical compe- 
tence is the ability to apply professional knowledge to perform a role to a defined standard.

This IES is addressed to International Federation of Accountants (IFAC) member bodies.

(3) This IES specifies the competence areas and learning outcomes that describe the technical competence required of aspiring professional accountants by the end of IPD.

Kembali mengingat pemikiran Ihde, kadang manusia berpikir mengapa mereka hidup seperti mesin. Lebih lanjut, beberapa hal konsensus yang berlaku di dunia akan menjadi dominasi dalam praktik kita. Maka benarlah yang disampaikan Ihde dikaitkan dengan kosep IES ini. Kita terjebak oleh kekuatan akal yang sarat dengan pemikiran Barat seperti penelitian Rahman (2003) yang mengistilahkannya dengan "the enlightenment of rationality and strong belief in the power of reason". Bukan hanya substansi kurikulum IES, kitapun terjebak kembali dengan keanggotaan IFAC yang mengikat dalam penerapan IES. Inilah teknologi "Ihde".

\section{Bagian II: Menelaah Ketidaksadaran Pengajar dalam Proses Pengajaran Akuntansi}

Kini perguruan tinggi disinyalir cenderung berorientasi pada kepentingan bisnis (Alexander 1996). Parameternya bisa saja dilihat dari jumlah penerimaan mahasiswa baru yang semakin meningkat. Namun di sisi lain, menurut Boyce (2004), model pengajaran saat ini cenderung fokus pada peningkatan keahlian (skill), bersosialisasi dengan lingkungan luar, serta mempersiapkan tenaga kerja untuk permintaan masa depan. Jadi pergeseran orientasi menjadi universitas bisnis tampak begitu jelas terlebih pada akhir dekade ini. Bukan hanya mahasiswa, pengajarpun menjadi layaknya mesin yang hanya mengikuti instruksi saduran luar negeri.

Memang kadangkala power cenderung mendominasi sesuatu lain yang termarginalkan (Triyuwono , 2011 menyebutnya “se laen"). Bagaimana sebuah ideologi dapat melegitimasi kepentingan sosial yang dominan?, Boyce (2004) mengutip Eagleton (1991) menjelaskan dominant power akan melegitimasi kekuatannya dengan menyebarkan nilai yang dibawanya melalui naturalizing dan universalizing yang tidak terelakkan, merendahkan pemikiran yang melawan kekua- tannya, mengeluarkan rival yang tidak sejalan dengan pemikirannya. Bukankah pernyataan ini mencerminkan apa yang sedang terjadi di Indonesia?. Bagaimana tidak, ketika di luar sana ada kekuatan adidaya yang telah dan sedang mencengkeram mangsanya, yang menelurkan universalisasi aturan/pedoman akuntansi, yang menolak pemikiran "unik" selain idenya, dan mengeluarkan mereka dari komunitas eksklusifnya bagi yang berseberangan.

Mungkin kita tidak menyadari ini sedang terjadi, atau mungkin sedang terlena dengan rasa nyaman karena keberuntungan kita sebagai bagian dari "pusat sosial" dan bukan sebagai bagian yang termarginalkan. Bergeser dari perbincangan tentang kondisi ini, peneliti akan melanjutkan hasil perbincangan berikutnya dari seorang mahasiswa pascasarjana yang baru saja menyelesaikan kuliah Master Ilmu Akuntansi. Panggil saja namanya "D". Menurutnya sejak dia menempuh kuliah sarjana sampai master tidak ada dosen yang menyampaikan tentang pelarangan praktik bunga, justru tambahnya, dulu banyak diajari bagaimana menghitung bunga diskonto, dan menentukan tingkat bunga bank. Berbeda dengan mahasiswa tingkat sarjana, si "D" ini menjelaskan lebih luas tentang riba. Berikut peneliti tampilkan kutipannya:

\footnotetext{
"Kalo menurutku sangat perlu untuk menyampaikan larangan riba meskipun dalam kelas ada beberapa mahasiswa non-muslim. Apalagi semua dosen yang mengajar mata kuliah akuntansi adalah muslim. Sebenarnya kalo bunga tidak dipandang dari segi agama, tapi dari segi mudharatnya, kita bisa menyampaikan itu. Karena memang mudharatnya riba itu merasuk ke berbagai segi kehidupan, tidak hanya dalam hal ekonomi saja”.
}

Informan keempat ini memang mengakui bahwa mata kuliah akuntansi sarat dengan perhitungan bunga. Namun dibalik proses ini, dari sarjana sampai master, sesungguhnya dia menyadari ketidaksesuaian metode pembelajaran yang diterimanya saat itu. Menurutnya, para pengajar yang kebetulan seluruhnya muslim memiliki kewajiban untuk menyampaikan tentang larangan riba, meskipun terdapat beberapa mahasiswa nonIslam. Memang kalau kita mencermati dampak riba, seperti yang telah peneliti singgung pada bagian sebelumnya, housing bubble price adalah satu siklus yang sangat relevan untuk mengilustrasikan multiplier effect atas praktik riba. 
Persis seperti ungkapan Rahman (2003), bahwa dalam pandangan Islam, segala sesuatu harus mengarah pada aspek relijius tanpa merugikan aspek duniawi. Melanjutkan pejelasannya, Rahman menilai bahwa pencapaian kebahagiaan dunia (human welfare in this life) dan akhirat (hereafter), tentunya harus tercermin dalam aktivitas ekonomi. Jadi, ekonomi seharusnya tidak dimaknai hanya sebagai pencapaian duniawi. Tidak hanya sebagai pemuas kebutuhan dunia melalui pencapaian laba maksimal.

"D" pun melanjutkan pendapatnya, "urgensi atas penyampaian pelarangan bunga ini agar muncul kesadaran dalam diri mahasiswa”. Nah, maka ini sejalan dengan pemikiran Ihde yang menurutnya aktivitas/perilaku seseorang sangat dipengaruhi oleh eksistensi teknologi. "Our involvement with technologies impacts our existential situation dramatically, particularly the way in which we understand our world and our humanity", tegas Ihde dalam upaya menggambarkan pengaruh tekonologi. Ketika manusia yang sedang terkotak oleh teknologi, maka mereka akan kehilangan kesadaran akan aktivitas yang sedang dilaksanakan. Oleh karena itulah, Ihde menyebutnya sebagai mesin dalam karyanya yang berjudul "Why Do Humans Think that they are a machines" (Selinger 2006:4). Jadi simpulan sementara dari hasil perbincangan dengan para informan menunjukkan bahwa para pengajar menjadi seperti mesin yang "disetir" oleh teknologi akuntansi meliputi pedoman pelaporan keuangan (PSAK, IFRS), standard kurikulum pendidikan (IES), dan buku referensi pengajaran berbasis western.

Informan terakhir, berbeda dengan keempat informan sebelumnya, yaitu seorang dosen. Bu "E" ini seorang dosen di salah satu perguruan tinggi yang pernah mengajar mata kuliah akuntansi di kelas internasional. Menanggapi beberapa pertanyaan peneliti, beliau berkomentar sebagai berikut:

"Iya mbak, saya akui saat itu saya tidak menyampaikan tentang larangan bunga karena riba. Tapi kalo seandainya saya sekarang diminta untuk mengajar peneliti akan lakukan itu. Menurut peneliti itu sangat penting disampaikan walaupun ada mahasiswa bukan Islam. Tinggal gimana cara kita nyampaikannya. Memang sih saat itu pemahaman peneliti tentang agama masih kurang. Tapi selain itu, peneliti rasa faktor buku referensi, dan karena riba ini tidak disampaikan di silabus juga berperan dalam membuat dosen itu menyampaikan sesuai dengan buku dan silabus”.

Hasil percakapan ini menguatkan hasil sebelumnya, yaitu pada bagian I, bahwa teknologi berupa buku referensi dan SAP (adaptasi dari IES) sangat mempengaruhi proses pembelajaran akuntansi keuangan. Para pengajar layaknya mesin yang menyampaikan ilmu tanpa sadar karena terperangkap dalam teknologi ala western yang cenderung sekuler (mengutip kembali Rahman 2003).

\section{Bagian III: Jadi, Bagaimana Seharusnya Proses Pembelajaran Akuntansi?}

Kita sudah sampai pada bagian terakhir dari pembahasan. Peneliti telah menceritakan hasil penelitian, teori relevan yang mendukung, kutipan standar, keterkaitan dengan pemikiran Ihde, dan tentunya justifikasi oleh diri peneliti atas beberapa hal. Sekarang saatnya peneliti mengungkapkan kondisi ideal yang seharusnya dilakukan oleh para pengajar ketika menyampaikan materi tentang pencatatan, pengakuan, dan pelaporan bunga dalam mata kuliah akuntansi keuangan khususnya. Menjawab pertanyaan di atas, bagaimana seharusnya?, jawabannya sederhana, "menghadirkan kesadaran para pengajar (dosen)". Meskipun tidak dapat bergerak bebas karena harus menerapkan standar kurikulum internasional, namun kita dapat menyampaikan materi tentang larangan praktik bunga beserta dampak ekonomi dan sosial atas riba. Karena riba bukan terbatas pada isu Islami, namun meluas sampai ekonomi makro yang mencakup elemen pemerintah dan masyarakat. Mari mengingat kembali siklus bubbling price yang berdampak pada seluruh sektor baik finansial maupun riil. Sektor riil inilah yang merasakan dampak paling besar atas peristiwa ini.

Penumbuhan kesadaran memang tidak dapat terbatas pada pengajar, namun mahasiswa pun perlu "dibangunkan", terlebih mereka yang telah menempuh beberapa mata kuliah yang terkait dengan bunga. Para mahasiswa inilah yang kelak akan menjadi penentu masa depan. Bukan hanya terbatas pada menggerakkan perekonomian, namun mereka juga berperan dalam menentukan arah pendidikan kelak. Inilah tugas utama kita sebagai pengajar untuk menularkan kesadaran yang berpedoman pada Al Quran dan Hadist. Jangan sampai kita dijuluki sebagai robot/mesin yang tanpa sadar sedang terjajah oleh "teknologi" yang tidak selaras dengan tujuan eksistensi 
manusia. Seperti dikutip dari Muqowim 2004 yang menyimpulkan bahwa ilmu yang digunakan untuk pengembangan peradaban manusia yang meliputi Al Qur'an dan AS-Sunnah harus bermuara pada Allah SWT. Ini dimaksudkan agar ilmu pengetahuan yang dimiliki manusia lebih khusus merujuk pada muslim, dapat menciptakan suatu peradaban islami yang mendasarkan pada kedua sumber tersebut.

\section{SIMPULAN}

Proses pengajaran akuntansi yang kini sedang berlangsung tampaknya menganalogikan kita (pengajar) sebagai mesin. Sebagai konsekuensi dari international membership, kita pun tidak dapat bebas bergerak karena batasan-batasan yang dibuat oleh standard setter. Selain itu, kitapun terjebak dalam kekakuan buku referensi yang tidak mengenal Tuhan dan agama. Buku referensi biasanya ditemani oleh standar pengakuan, pengukuran, dan pelaporan yang mengadaptasi dari Barat. Padahal menurut beberapa peneliti seperti tersebut sebelumnya, menyatakan bahwa Barat itu sekuler dan senantiasa mengedepankan rasionalitas. Salah satu konsepnya berupa penerapan bunga yang diyakini oleh Islam sebagai riba. Sesungguhnya riba bukanlah sebatas isu Islami, namun mendasarkan pada siklus housing bubble price yang berdampak pada seluruh sektor, maka praktik bunga seharusnya dapat dipahami sebagai isu universal.

Ihde menyebut kondisi ini sebagai manusia mesin. Manusia yang hidup tanpa memiliki kesadaran atas apa yang telah dan sedang dilakukannya. Ini dikarenakan mereka didekte oleh teknologi Barat yang cenderung rasionalis dan statis. Telah tiba saatnya bagi kita untuk bangun, dan menumbuhkan kesadaran atas diri sendiri dan mahasiswa. Proses ini tentu membutuhkan waktu. Namun jika tidak segera diawali, mungkin saja suatu saat Indonesia menjadi boneka negara Barat. Wallahualam bi showab.

\section{DAFTAR PUSTAKA}

Aliyev, F. B. 2007. Problems of Interaction Between State and Economy under the Post-Communist Transition. Hunaomics, 23 (2), 78-82.

Ardiansyah, Y. 2009. Kinerja Keuangan Perbankan Syariah di Indoneisa dan Kontribusinya bagi Pembangunan Nasional. Jurnal Ekonomi islam La_Riba, 3 (2), 80-196.

Boyce, G. 2004. Critical Accounting Education: Teaching And Learning Outside The Circle. Critical Perspectives on Accounting, 15, 565-586.

Chong, B.S dan M. H. Liu. 2009. Islamic Banking: Interest-free or Interest-Based?. Pacific-Basin Finance Journal, 7, 125-144

Choudhury, M.A. 2008. Islam Versus Liberalism: Contrasting Epistemological Inquiries. International Journal of Social, 35 (4), 239268.

Hadisumarto, W. M. C dan A. G. B. Ismail. 2010. Improving the Effectiveness of Islamic micro-financing (Learning from BMT Experience), Working Paper.

Haniffa, R dan M. Hudaib. 2010. Islamic Finance: from Sacred Intentions to Secular Goals?. Journal of Islamic and Business Research, 1 (2), 85-91.

Hayat, R dan R. Kraeussl. 2011. Risk and Return Characteristics of Islamic Equity Funds. Emerging Markets Review, 12, 189-203.

Henry, C. M dan R. Springborg. 2001. Globalization and the Politics od Development in the Middle East. UK: Cambridge University Press.

Holt, J. 2009. A Summary of the Primary Causes of the Housing Bubble and the Resulting Credit Crisis: A Non-Technical Paper. The Journal of Business Inquiry, 8 (1), 120-129.

Kamla, R. 2009. Critical Insights into Contemporary Islamic Accounting. $E$ Critical Perspectives on Accounting, 20, 921-932.

Khan, F. 2010. How 'Islamic' is Islamic Bank?. Journal of Economic Behaviour \& Organization, 7, 805-820.

Lehman, C. R. 2012. Knowing the Unknowable and Contested Terrains in Accounting. Critical Perspectives on Accounting, 24, 136-144.

Mulawarman, A. D. 2013. "Nyanyian Metodologi Akuntansi Ala Nataatmadja: Melampaui Derridian Mengembangkan Pemikiran Bangsa "Sendiri”. Jurnal Akuntansi Multiparadigma, 4 (1), 149-164.

Nofianti, L. 2012. Kajian Filosofis Akuntansi: Seni, Ilmu, atau Tekonologi. Pekbis Jurnal, 4 (3), 203-210.

Rahman, A. R. A. 2003. Ethics in Acoounting Education: Contribution of the Islamic 
Principle of Maslahah. Journal of Economics and Management, 11 (1), 1-17.

Selinger, E. 2006. Phenomenology: a Critical Companion to Ihde. Albany: State University of New York Press.

Siddiqi, M. N. 2004. Riba, Bank Interest, and the Rationale of Its Prohobition. Jeddah: Islamic Development Bank.

Triyuwono, I. 2011. Mengangkat "Sing Liyan" untuk Formulasi Nilai Tambah Syari'ah. Jurnal Akuntansi Multiparadigma, 2 (2), 186-200.

Wahyudi, I, M. K. Dewi, F. Rosmanita, M. B. Prasetyo, N. I .S . Putri, B. M. Haidir. 2013. Manajemen Risiko Bank Islam. Jakarta: Salemba Empat. 